\title{
Applying Standardized Rubrics for Assessing the Instructional Competence of Elementary School Teachers (EST) in Pakistan
}

\author{
Syed Zubair Haider \\ Department of Education \\ The Islamia University of Bahawalpur, Pakistan \\ Muhammad Qasim \\ Department of Education \\ The Islamia University of Bahawalpur, Pakistan \\ Salma Ameen \\ Department of Education \\ The Islamia University of Bahawalpur, Pakistan
}

\begin{abstract}
The current study examines the Elementary School Teachers' (ESTs) instructional competence through standardized rubrics developed under guidance of Government of Pakistan and UNESCO. The main purpose of this research was to explore the current position of competencies of ESTs, to evaluate the various competencies of ESTs described in the National Professional Standards for teachers in Pakistan and advocate certain measures to improve the competencies and evaluation mechanism of ESTs. The population of the study comprised of male and female ESTs working in government schools located in urban and rural areas of district Lodhran, Punjab Pakistan. To conduct the observational survey 225 ESTs were selected randomly. An observational checklist was made on recommended grounds of teacher accreditation by Policy and Planning wing of Ministry of Education, Pakistan and UNESCO. The Statistical Package for Social Sciences (SPSS version 19) was utilized to analyze the collected data. A number of descriptive statistics including Chi Square, mean and percentage were calculated. The study concludes that most of ESTs were found week in various teaching competencies.
\end{abstract}

Keywords: Subject Matter, Assessment, Teachers Competence, Human Development, EST, UNESCO, USAID, Professional Standards.

\section{INTRODUCTION}

In the entire process of education, the position of teacher is a very important factor. The more a teacher is competent and qualified, the better the level of excellence in education is secured. Teachers serve as a major factor for on ground implementation of educational reforms. They are legitimately taken as change-agents at the grass-root level. A mass of factors play role in the formation of teacher education and its quality in our country. It involves ideology and socio-economic requirements as well as the structure and theories in vogue. Among the integral components of education system the programmes of teacher education hold a significant place. These programmes would develop through new dimensions with view to the new needs of the future. The matter of quality in teacher education is a concern of policy and planning in the education fascia.

Other major areas of concern in this context are teacher education programmes, proper infrastructure, pre-service and in-service refreshers for educators in teacher training, replacement of material and methods, techniques of evaluation and instructional materials [9]. 
The personality of a teacher is featured with many traits which need grooming and development. That can be executed through training. Many new techniques have been devised and are being applied in the current scenario of education throughout the world for raising the level of teacher's competence. It is remarkable that teacher training formats are not alike for all as is for other professionals [18].

The national professional standards in Pakistan regarding teacher training hold that national development rests on quality of education [10]. The national education system in our country assigns high importance to teacher education; reason thereof is wide scale acknowledgement that quality of elementary education can be raised through teachers with proper quality training in the institutes of teacher education [19]. It is unfortunate that several deficiencies exist in the teacher education in Pakistan; what is being taught in teacher education institutions is not what we need in our classrooms. So such trainings do not help much the teachers in effective teaching. So, problems of poor teaching in our schools have been under study over the decades.

Therefore, the teacher education has become a prime concern at elementary, secondary and higher secondary levels in Pakistan. Teacher education refers to programmes of training human resource to equip them with skills in teaching at primary, elementary and secondary stages as well as for programmes of non-formal and part-time education that includes adult education and correspondence education [16]. The National Commission on Education reported that the education system in the country immediately needed qualified and trained teachers [8]. According to recommendation of the commission, the teachers must be adequately trained in teaching of their respective subjects. They must be versed with proper understanding of children and must possess sense of honour in profession [2].

\section{Teacher Competence}

Generally competence is taken as quality of performance [13]. Quality of specific behavior which can be identified in summation of behavior is termed as competence. It is extent of quality of behavior that produces desired performance for discharge of a particular duty. Competence does not refer to a single and direct act like particular habits or specific knowledge. It refers to a totality of behaviors as evident through overall activities. Moreover, competence is a vibrant mode of work. It stands like an estimate as long as real situation of performance turns it into actual demonstration.

Competence of a teacher means his teaching skills, power and potential in satisfactory performance of his functions. Teacher's competence is not necessarily the same like 'teacher's performance' or 'teacher's effectiveness'. This is indeed a stable feature of teacher's faculties that do not change with the change in work situations. Competence of a teacher is in-fact his cognitive knowledge that affects on learning of students.

Kalra suggest that there are two major divisions of competence. (a) Cognitive skills and mental abilities of a teacher; this involves psychological and educational perceptions and knowledge of subject on part of the teacher. (b) Interests and attitudes of a teacher; this involves behavior and beliefs and relationships of the teacher with pupils and others around the workplace [13].

Siddiqui [20] identifies eight while Sinha [21] define seven competencies of teachers described as on the next page. 
Haider, S.Z., Qasim. M., \& Ameen. S. (2015). Applying Standardized Rubrics for Assessing the Instructional Competence of Elementary School Teachers (EST) in Pakistan. Advances in Social Sciences Research Journal, 2(3) 38-50.

Table No l: Comparison of Teachers Competencies

\begin{tabular}{|l|l|l|}
\hline Sr. No & Siddiqui (2004) Author-A & Sinha (2007) Author-B \\
\hline $\mathbf{1}$ & Academic competencies & Conceptual competencies \\
\hline $\mathbf{2}$ & Methodological competencies of teachers & Curricular and content competencies \\
\hline $\mathbf{3}$ & Lesson planning & Teacher with content management skill \\
\hline $\mathbf{4}$ & Use of questions & Teacher of high values and morality \\
\hline $\mathbf{5}$ & Improvement of student attitudes & Teacher managing identity crises \\
\hline $\mathbf{6}$ & Classroom management & Learner center teacher \\
\hline $\mathbf{7}$ & Time management skill & Teachers with global vision and speed \\
\hline $\mathbf{8}$ & Development of self-confidence in students & \\
\hline
\end{tabular}

The above table l showed that performance of a teacher primarily depends upon his knowledge. This encompasses general pedagogy and subject matter knowledge, which linked it directly with competence of teacher, his characteristics and attitudes. Similar concept matches with many other researchers said that for the good performance of a teacher, subject matter is highly important; this is as suggested in qualitative research that knowledge of content affects what a teacher teaches and how he teaches. Further, the subject matter is associated with pedagogical skills in connection with management of classroom, structure of lesson and method of teaching. He further described that inadequate professional training obstructs full play of teacher's competencies.

The stature of education in any community is determined with competence and commitment of the teachers on work. The entire set of policies, objectives, curricula, programmes, equipments and establishments is nothing more than a skeleton; and the life of it is the 'teacher'. Whatsoever efforts may be made to improve the entire structure that would be of no avail unless the teacher's competence is raised? Primarily, the ability of educating and teaching is not for granted, nor it comes by birth; rather it is a skill that is acquired through teaching training [14]. A teacher must be competent because his competence carries the ability to provide desired reinforcement and to release tensions from the classroom teaching learning process. This would ultimately bring about facilitation in the development of positive feelings among the students undergoing the process of education.

\section{Assessment of Teacher Competence}

It is generally believed that success of educational process is connected with quality of teaching in the classroom [11]. It leads to the simple professional conclusion that competence of a teacher is integral and success of teaching learning process is depending on it. Here the question arises - how to measure or assess the competence of a teacher. That is indeed prolong and complex process because evaluation of teacher's work is made through evaluation of students' performance and achievements. Besides this, distinguishing between various levels of competence and skills is not very plain in evaluation. A test of teacher's competence should include knowledge of subject contents taught in the formal learning process plus general knowledge usually expected in possession of the students [15].

According to Popham [17] the teacher and the school are evaluated according to the learning and achievement "outputs" of their students. In addition, the measurement of teacher competence in terms of pupils" performance is often difficult because many variables are involved. Formal written test of knowledge are major tools used in assessment of teacher competence [6]. Among these tools are observation schedule, rating scales and data collection related to teacher's impact on students' progress in readily defined goals of education. Thus all probabilities exist that such data consist upon achievement tests of students. It can be finely and finally extracted that there is an intrinsic link between the performance of a teacher and achievements of the students. This reciprocal link brings emphasis on the argument that 
performance of student in an assessment necessarily becomes a component of performance evaluation of a teacher [22].

During the previous decade, a remarkable work has been done to draw a framework in the following three areas: a) what are and should be the testing system made for improving the instructional system; b) which type of knowledge and abilities are/should be required for the teachers to design a standard for the preparation of teacher training program; and c) the linkages between the input by the teachers and their outcome. Moreover, innovation in measurement, assessment and evaluation techniques/strategies for teachers has been applied in the United States. These techniques/strategies the assessment of teacher performance comes close to the development and enhancement of teaching skills [22].

\section{Development of Rubrics}

Rubric is one among the scoring scales and guideline used for assessment of students' performance and learning products. This tool is utilized in a multiple ways for advancement of students learning. Experts trust in potential of rubrics as they contribute to students learning and serve finely for non-traditional testing and evaluation. Rubrics bring improvement in teaching and make assessment better. Rubrics are also high value source of information wanted and used for improvement of any programme. Despite acknowledgeable value of rubrics, it has been observed that rubrics are mostly set aside in context of higher education. Rubrics ensure multi-purpose scoring of students work in any assessment process. There are multiple ways wherewith rubrics serve to advance the goals of any programme. Thus improvement of teaching, provision of feedback for students and contribution towards reliable assessment are some of major feature of rubrics in educational assessment.

As an instance, a rubric make more clear rating of performance for judges in board pitching mechanism. Still the judges would be seeking to weigh upon their broader vision and their professional knowledge in application of rubric criteria. Similarly, for providing suitable instructions to the players and athletes, coaches study the criteria of rubrics; also the athletes go through the criteria for making plans and bringing perfection in their sports. On the same lines, for a course assignment or other learning segments, involving more than one participant, best learning can be executed if and when all participants are well versed of the work scheme for performance the level of assessment for that performance.

Through bringing betterment in quality of teachers and teaching processes, many initiatives have been taken by the Govt of Pakistan leading to ultimate improvement of quality of education. In order to secure this needful, professional standards of teacher education are on priority of quality assurance. With the collaboration of UNESCO, the Policy and Planning Wing of Ministry of Education has taken up a comprehensive programme titled as STEP (Strengthening Teacher Education in Pakistan) for which necessary funding was extended by the USAID. The professional standards under this programme are focusing primary level teachers and can be replicated with necessary adaptation for elementary level teaching as well. The standard of professional knowledge and skills address competencies, dispositions and attributes which are considered necessary for educators. These standards determine the way to develop pre-service and in-service training programmes for teachers. These standards also help in setting the direction of policies, procedures and systems for accreditation. Similarly, institutions that offer such training under this programme amply ensure the quality of their results and products [23]. 


\section{Statement of the Purpose}

Teacher is the change agent in education system which plays a pivotal role to improve the quality of education. Quality of education mainly depends how quality of teaching is taking place in classroom teaching. For this purpose teacher plays very important role to ensure maximum learning during classroom teaching. Ministry of education Pakistan has launched national professional standards to get better the educational quality through improving teacher's educational performances in Pakistan. The study was designed to examine Standardized Rubrics for Assessing the Instructional Competence of Elementary School Teachers (EST) in Pakistan. These rubrics are designed by ministry of education Pakistan in collaboration with UNESCO and USAID.

\section{RESEARCH METHODOLOGY}

The study utilized quantitative approach which incorporates survey for descriptive research.

\section{Population and Sampling}

The study population comprised of all elementary school teachers (ESTs) serving in government sector urban and rural schools of district Lodhran. Simple random sampling technique was used which according to [3] provide basis for all statistical analyses. Sample was collected from Lodhran district which includes three tehsils (Lodhran, Dunya Pur and Kehror Pacca). Total numbers of ESTs in district Lodhran are approximately 13000. To conduct this research study, a sample of 225 ESTs was chosen to examine their teaching competencies. The size of sample was streamlined as suggested by experts to select from the size of population i.e. if the population of a research study is 10,000 and above, the size of sample should be $1 \%$ as appropriate hence researcher has taken $2 \%$ sample to overcome the chance of error in sample.

\section{Research Instrument}

The quantitative approach was used to fulfill the need of the research problem because the observational checklist was the appropriate tool for the analysis of ESTs' performance. The competencies of demonstration, practice and application of ESTs were observed by the researcher. So, the efficiency of teacher competence was evaluated by using the observation sheet and it was designed on the basis of already defined levels of teacher accreditation by Policy and planning wing of Ministry of Education, Pakistan in collaboration with UNESCO. The Observation sheet was prepared on the basis of national professional standard for teachers in Pakistan. This observation helped the researcher to collect the empirical evidences of their practices in the classroom teaching. Each standard was further divided according to its predetermined factors i.e. knowledge and understanding, disposition and performance skills.

\section{Description of Scales of Observation}

Table No 2: Levels of Observation

\begin{tabular}{|c|c|c|c|c|c|}
\hline Sr. No & Level-0 & Level-1 & Level-2 & Level-3 & Level-4 \\
\hline 1 & Not Demonstrated & Emerging & Developing & Proficient & Accomplished \\
\hline 2 & Not at All Aware & Slightly Aware & Sometime Aware & Moderately Aware & Extremely Aware \\
\hline
\end{tabular}

criteria used in the evaluation of the teacher's skills in each of listed area

Table No 3: Description of Scale

\begin{tabular}{|c|c|c|}
\hline Sr. No & Scale & Description \\
\hline 1 & A rating scale of 0 & Means the teacher does not have this competency at this time. \\
\hline 2 & A rating scale of 1 & Means the teacher has some difficulty of demonstrating this competency. \\
\hline 3 & A rating scale of 2 & Means the teacher has done a satisfactory job for demonstrating this competency \\
\hline 4 & A rating scale of 3 & Means the teacher has done a good job of demonstrating this competency. \\
\hline 5 & A rating scale of 4 & Means the teacher has done an excellent job of demonstrating this competency. \\
\hline
\end{tabular}

On the basis of this observation scale, rubrics developed by USAIDs and Ministry of Education, Pakistan, for gauging teachers competencies. 


\section{Validation of Research Tool}

The research instrument (Observation sheet) was distributed among ten experts from different universities for evaluation and validation. After getting feedback from experts, instrument was further distributed among some faculty members and research students of education department to get suggestions for further modifications and the research tool was finalized with the due reconsideration. With this the instrument was all set for applying to examine the dependability, reliability and trustworthiness. Pilot study was conducted at five government schools to test and ensure the reliability of the research instrument. The calculated reliability score of the observational check list was found (Cronbach's alpha .921) by overall that is reliable and valid because 0.70 and above values are reliable [12].

\section{Data Collection and Analysis}

The researchers personally collected the required information from district Lodhran. For collecting data, the beforehand permission and willingness in black and white was sought from sample population. The collected data was analyzed with Statistical Package for Social Sciences (SPSS) version 19 by using statistical formulas of Chi-Square and percentage. The evaluation of ESTs competencies was analyzed item wise. After analysis, the findings were reported and on the basis of these findings, appropriate measures were suggested for further improvements in the existing standards of teachers' performance.

\section{RESULTS}

The study was designed to assess the various competencies of Elementary School Teachers. An observation sheet was prepared to collect data and it was analyzed through SPSS. The results deal with the analysis and interpretation of the data in the light of the aims of the study.

\section{Table No 4: Standard (1) Subject Matter Knowledge}

\begin{tabular}{|c|c|c|c|c|c|c|}
\hline Response & $\begin{array}{l}\text { Level } \\
0\end{array}$ & $\begin{array}{l}\text { Level } \\
1\end{array}$ & $\begin{array}{l}\text { Level } \\
2\end{array}$ & $\begin{array}{l}\text { Level } \\
3\end{array}$ & $\begin{array}{l}\text { Level } \\
4\end{array}$ & $X^{2}$ \\
\hline Teacher understands the national curriculum framework & 4 & 26.2 & 47.1 & 22.7 & 0 & 356.41 \\
\hline $\begin{array}{l}\text { Teacher knows how to relate the subject knowledge with } \\
\text { other discipline/subject. }\end{array}$ & 4 & 35.1 & 40 & 20 & 0.9 & 236.76 \\
\hline $\begin{array}{l}\text { Teacher facilitates students in learning by using different } \\
\text { teaching techniques }\end{array}$ & 2.7 & 16.4 & 48 & 30.7 & 2.2 & 178.69 \\
\hline $\begin{array}{l}\text { Teacher values to make knowledge applicable in real world } \\
\text { situation }\end{array}$ & 0.9 & 48.4 & 38.2 & 12 & 0.4 & 450.98 \\
\hline $\begin{array}{l}\text { Teacher values the diverse talents of all students to develop } \\
\text { confidence }\end{array}$ & 0.9 & 20 & 48.9 & 28.9 & 1.3 & 209.45 \\
\hline Teacher explains the content knowledge in multiple ways & 1.3 & 13.3 & 62.2 & 17.3 & 1.8 & 265.98 \\
\hline $\begin{array}{l}\text { Teacher uses appropriate inquiry tools according to the } \\
\text { students' prior knowledge }\end{array}$ & 2.7 & 19.6 & 56 & 20.4 & 1.3 & 322.34 \\
\hline $\begin{array}{l}\text { Teacher demonstrates subject knowledge relating it with } \\
\text { practical life of the students }\end{array}$ & 1.8 & 26.7 & 55.6 & 13.3 & 2.7 & 343.54 \\
\hline Teacher knows to construct students' knowledge & 0.4 & 16 & 44 & 20.9 & 18.7 & 235.43 \\
\hline $\begin{array}{l}\text { Teacher knows to influence students' learning through } \\
\text { cultural background }\end{array}$ & 0.9 & 12.4 & 42.7 & 40.4 & 3.6 & 287.54 \\
\hline $\begin{array}{l}\text { Teacher knows the factors affecting the students' } \\
\text { performance }\end{array}$ & 0.9 & 14.7 & 54.7 & 28.4 & 1.3 & 398.65 \\
\hline
\end{tabular}

Result of responses for subject matter knowledge showed that they are all significant at alpha level 0.05 . The result of response 1 manifest that most of the elementary school teachers were found at level-2 (developing teacher) and no one found at desire level of competency while teacher knowledge to relate subject knowledge with other discipline concludes that most of the elementary school teachers were found at level-1 (Emerging teacher). In response 3 most of the teachers were found at level-2 and were facilitate students according to the desired learning outcomes hence an undersized numbers of teachers were found at desire level. 
Teacher values to make knowledge applicable in real world situation showed that most of the elementary teachers teaching in government school were found at emerging level teachers, a negligible number of teachers value to make knowledge applicable.

Teacher values the diverse talents of all students to develop confidence concludes that most of the elementary school teachers occasionally value the diverse talents of students. A negligible numbers of teachers were found competent and were at level-4 in this rubric while results of response 6 showed that majority of the teachers almost every explain content knowledge in multiple ways while a very few teachers were placed as accomplished teachers and found competent. On the other hand, the results of the teachers uses appropriate inquiry tools according to the students' prior knowledge concludes that most of the teachers occasionally use appropriate inquiry tools according to the students' prior knowledge and were found at level-2 while a very limited number of teachers were found competent in this rubric.

While Teacher demonstrates subject knowledge relating it with practical life of the students described that the majority of the elementary school teachers teaching in district Lodhran were found at proficient teacher in this rubric A insignificant number of teacher were found at desire level of competency. Response 9, teacher knows to construct students' knowledge emerged that less than half of the teachers were found at developing level hence few elementary school teachers were observed at desire level of competency in above rubric and called as accomplished teachers while the response 10 manifest that most of the teachers were found at developing and proficient level. A very few teachers were found at desire level of competency. Teacher knows the factors affecting the students' performance conclude that no one elementary school teacher was found at desire level of competency in teacher knowledge of factor affecting the students' performance. Most of teachers were place at level-3 (Proficient teacher).

Table No 5: Standard (2) Human Growth and Development

\begin{tabular}{|c|c|c|c|c|c|c|}
\hline Response & $\begin{array}{l}\text { Level } \\
0\end{array}$ & $\begin{array}{l}\text { Level } \\
1\end{array}$ & $\begin{array}{l}\text { Level } \\
2\end{array}$ & $\begin{array}{l}\text { Level } \\
3\end{array}$ & $\begin{array}{l}\text { Level } \\
4\end{array}$ & $X^{2}$ \\
\hline Teacher understands individual differences among students & 0.9 & 9.8 & 40 & 48.4 & 0.9 & 198.89 \\
\hline Teacher knows diverse style of learning. & 2.2 & 30.7 & 41.3 & 24.4 & 1.3 & 247.34 \\
\hline Teacher is aware of how to use motivational strategies & 1.3 & 23.1 & 47.1 & 27.1 & 1.3 & 222.46 \\
\hline Teacher appreciates the multiple ways of getting knowledge & 0.4 & 19.6 & 36.4 & 42.2 & 1.3 & 349.22 \\
\hline Teacher is committed to develop critical thinking of students & 0.9 & 22.2 & 62.2 & 12.9 & 1.8 & 435.34 \\
\hline Teacher values to treat all students equitably & 2.2 & 12 & 24 & 60 & 1.8 & 178.69 \\
\hline $\begin{array}{l}\text { Teacher engages in activities to promote creative thinking of } \\
\text { students }\end{array}$ & 1.8 & 20.9 & 44.9 & 32 & 0.4 & 389.32 \\
\hline $\begin{array}{l}\text { Teacher uses instructional technologies to develop problem } \\
\text { solving skills }\end{array}$ & 2.2 & 22.7 & 54.2 & 18.7 & 2.2 & 237.34 \\
\hline $\begin{array}{l}\text { Teacher understands to promote the general values among } \\
\text { students }\end{array}$ & 0.4 & 12.9 & 53.3 & 30.7 & 2.7 & 321.35 \\
\hline Teacher knows the importance of peace in society & 0.9 & 9.8 & 39.1 & 49.3 & 0.9 & 398.07 \\
\hline
\end{tabular}

The results of the responses percentage for human growth and development standard emerged that all are significant at alpha level 0.05 . The results of the response 12 , teacher understands individual differences among students concluded that very limited number of teachers was found at desire level of competency. Most of teachers were al level-3 (Proficient teacher) that they were aware about individual difference of students while teacher knows diverse style of learning showed that a negligible number of teachers were found at desire level of competency in above mention rubric. Most of teachers were al level-3 (Proficient teacher) that they were aware about diverse learning style. Teachers are aware of how to use motivational strategies concludes that very little number of teachers was found at desire level 
of competency in above mention rubric. Most of the teachers were placed under the category of level-2 that they little bit use motivational strategies during classroom teaching.

Teacher appreciates the multiple ways of getting knowledge response 15, showed that very limited teachers were found at desire level of competency in above rubric. Most of the teachers were placed under the category of level-3 that they almost every time appreciate the multiple ways of getting knowledge. On the other hand, teachers are committed to develop critical thinking of students found that very limited teachers were found at desire level of competency in above mention rubric. Most of the teachers were placed under the category of level- 2 that they occasionally develop critical thinking of students. Teacher values to treat all students equitably showed that very small number of teachers was found at desire level of competency. Most of the teachers were placed under the category of level-3 that they almost every time values to treat all students equitably while response 18, described that negligible number of teachers was found at desire level of competency in rubric promote creative thinking of students. Most of the teachers were placed under the category of level-2 that they occasionally promote creative thinking of students.

Teacher uses instructional technologies to develop problem solving skills response 19, concludes that very limited teachers were found at desire level of competency in rubric use of instructional technologies to develop problem solving skills. Most of the teachers were placed under the category of level-2 that they occasionally use instructional technologies to develop problem solving skills while in response 20 , showed that a negligible number of teachers were found at desire level of competency in above mention rubric. Most of teachers were al level-2 (developing teacher) that they understand how to promote the general values among students. Teacher knows the importance of peace in society manifest that a negligible number of teachers were found at desire level of competence in above mention rubric. Most of elementary school teachers usually know the importance of peace in society.

Table No 6: Standard (3) Knowledge of Islamic Ethical Values/Social Life Skills

\begin{tabular}{|c|c|c|c|c|c|c|}
\hline Response & $\begin{array}{l}\text { Level } \\
0 \\
\end{array}$ & $\begin{array}{l}\text { Level } \\
1 \\
\end{array}$ & $\begin{array}{l}\text { Level } \\
2\end{array}$ & $\begin{array}{l}\text { Level } \\
3 \\
\end{array}$ & $\begin{array}{l}\text { Level } \\
4 \\
\end{array}$ & $X^{2}$ \\
\hline Teacher knows the impact of bias on students learning & 0.9 & 11.6 & 48 & 39.1 & 0.4 & 367.98 \\
\hline $\begin{array}{l}\text { Teacher knows the principles of Islamic ideology in the } \\
\text { textbooks }\end{array}$ & 0.9 & 12 & 46.2 & 39.6 & 1.3 & 245.76 \\
\hline $\begin{array}{l}\text { Teacher inculcates the Islamic values of students' ethical } \\
\text { training }\end{array}$ & 0.9 & 11.1 & 50.7 & 36.9 & 0.4 & 129.34 \\
\hline Teacher values the cultural background for individuals respect & 2.7 & 8 & 45.3 & 42.7 & 1.3 & 242.87 \\
\hline Teacher believes in dialogues as a means to solve conflict. & 1.3 & 12.4 & 42.2 & 42.2 & 1.8 & 376.76 \\
\hline Teacher believes in practicing moral values in school & 1.3 & 32 & 35.1 & 30.7 & 0.9 & 188.89 \\
\hline $\begin{array}{l}\text { Teacher creates a learning community in which individuals are } \\
\text { respected }\end{array}$ & 1.3 & 12.4 & 52 & 32.9 & 1.3 & 341.6 \\
\hline Teacher practices Islamic teachings to create harmony & 3.6 & 11.1 & 42.2 & 42.2 & 0.9 & 234.54 \\
\hline Teacher solves conflicts through Islamic teachings & 2.2 & 12.4 & 57.8 & 26.7 & 0.9 & 239.54 \\
\hline
\end{tabular}

The results of the responses for Knowledge of Islamic Ethical Values/Social Life Skills standard emerged that all are significant at alpha level 0.05. Knowledge of bias on students learning is very important aspect for teacher at every level. Knowing about the impact of bias helps teachers to understand and share equal opportunities in classroom teaching. This analysis concluded that no one EST was found at desire level of competency (level 4) that know the impact of bias on students learning, hence majority of them were demonstrating poor performance that almost ever demonstrated biased on students learning while the teacher knows the principles of Islamic ideology in the textbooks response 23, showed that a negligible numbers of teachers were found at competent level while most of the teachers were not having competency at desire level in this rubrics. On the other hand, the result of response 24 showed 
that very limited teachers were found at desire level of competency in rubric. Most of the teachers were placed under the category of level-2 that they occasionally inculcate the Islamic values of students' ethical training.

Teacher values the cultural background for individuals respect demonstrate that very few teachers were found at desire level of competency in rubric. Most of the teachers were placed under the category of level-2 that they occasionally value the cultural background for individuals respect. The result of response 26 demonstrates that a few teachers were found at desire level of competency in rubric "Teachers believe in dialogues as a means to solve conflict". Most of the teachers were placed under the category of level-2 and level-3 that they occasionally believe in dialogues as a means to solve conflict. The response 27, analysis concludes that a few teachers were found at desire level of competency in rubric "Teacher believes in practicing moral values in school". Most of the teachers were placed under the category of level-3 that they occasionally believe in dialogues as a means to solve conflict.

Teacher creates a learning community in which individuals are respected concluded that almost half of the teachers were found at level-2 (developing teacher) they every so often create learning community in which individuals are respected. A minor number of students were found at desire level of competence. Empirically it can be said that a few teachers were found at desire level of competency in rubric "Teacher practices Islamic teachings to create harmony". Most of the teachers were placed under the category of level- 2 and level- 3 that they occasionally practice Islamic teachings to create harmony. In response 30, it is It is concluded that almost half of the teachers were found at level-2 (developing teacher) they sometimes solve conflicts through Islamic teaching. A negligible number of teachers were found at desire level of competence.

Table No 7: Standards (4) Instructional Planning and Strategies

\begin{tabular}{|c|c|c|c|c|c|c|}
\hline Response & $\begin{array}{l}\text { Level } \\
0\end{array}$ & $\begin{array}{l}\text { Level } \\
1\end{array}$ & $\begin{array}{l}\text { Level } \\
2\end{array}$ & $\begin{array}{l}\text { Level } \\
3\end{array}$ & $\begin{array}{l}\text { Level } \\
4\end{array}$ & $X^{2}$ \\
\hline Teacher knows objectives of curriculum & 1.8 & 25.3 & 46.7 & 25.8 & 0.4 & 276.67 \\
\hline $\begin{array}{l}\text { Teacher knows to promote students' learning through available } \\
\text { resources }\end{array}$ & 1.3 & 18.2 & 45.3 & 35.1 & 0 & 312.34 \\
\hline $\begin{array}{l}\text { Teacher knows a variety of instructional approaches for } \\
\text { students' understanding }\end{array}$ & 6.2 & 23.1 & 44.9 & 25.8 & 0 & 254.62 \\
\hline Teacher is committed to attain curriculum objectives & 4 & 20.4 & 48.4 & 27.1 & 0 & 321.5 \\
\hline Teacher values pedagogy of collaboration & 3.1 & 20 & 56.4 & 20 & 0.4 & 387.9 \\
\hline Teacher values the multiple ways of problem solving & 2.7 & 40 & 33.8 & 21.3 & 2.2 & 320.45 \\
\hline $\begin{array}{l}\text { Teacher engages in activities to design instructions to students' } \\
\text { age }\end{array}$ & 4 & 22.7 & 45.8 & 27.6 & 0 & 187.8 \\
\hline $\begin{array}{l}\text { Teacher plans out of class activities to make student learning } \\
\text { better }\end{array}$ & 2.2 & 18.2 & 45.8 & 33.3 & 0.4 & 425.65 \\
\hline Teacher organizes instructional activities for effective lesson & 2.7 & 16 & 37.3 & 43.1 & 0.9 & 330.66 \\
\hline
\end{tabular}

The results of the responses for Instructional Planning and Strategies standard emerged that all are significant at alpha level 0.05 . The analysis concludes that few teachers were found at desire level of competency in rubric teacher knows the objectives of curriculum. Most of the teachers were not having clear concept about objectives of curriculum while it also showed that no one was found at desire level of competency in rubric. Teacher knows how to promote students learning through available resources. Most of the teachers were found at level- 2 . The results of response 34 showed that most of teachers were found at level-2 (developing teacher) they sometimes know a variety of instructional approaches for students understanding but not a single teacher was found at desire level of competence. 
Teacher committed to attain curriculum objectives. Most of the teachers were placed under the category of level-2 that occasionally committed to attain curriculum objectives. On the other hand, it may be said that small numbers of ESTs were found at desire level of competency in rubric. In response of teacher valuing pedagogy of collaboration, most of the teachers were placed under the category of level-2 (Developing teacher). It can also be said that negligible numbers of elementary school teachers were found at desire level of competency in rubric. Teacher value the multiple ways of problem solving, most of the teachers were placed under the category of level-2 (Developing teacher).

Response 41 showed that no one teacher was found at desire level of competency in rubric. Teacher engages in activities to design instructions to students' age, most of the teachers were found at level-2. Planning for out of class activities was assumed necessary for teacher as planning for out of class activities helps to accelerate, extend and consolidate student learning. It is cleared that a little number of ESTs were found at desire level of competency in rubric. Teacher plan out of class activities to make student learning better, most of the teachers were placed under the category of level-2 (Developing teacher). It can also be said that negligible numbers of elementary school teachers were found at desire level of competency in rubric. Teachers organize instructional activities for effective lesson. Most of the teachers were under the category of level-3 (Proficient teacher).

Table No 8: Standard (5) Assessment

\begin{tabular}{|c|c|c|c|c|c|c|}
\hline Response & $\begin{array}{l}\text { Level } \\
0\end{array}$ & $\begin{array}{l}\text { Level } \\
1\end{array}$ & $\begin{array}{l}\text { Level } \\
2\end{array}$ & $\begin{array}{l}\text { Level } \\
3\end{array}$ & $\begin{array}{l}\text { Level } \\
4\end{array}$ & $X^{2}$ \\
\hline $\begin{array}{l}\text { Teacher assesses the students through formal and informal } \\
\text { methods }\end{array}$ & 2.2 & 14.2 & 26.7 & 55.6 & 1.3 & 254.76 \\
\hline Teacher knows various methods of assessment & 1.8 & 15.6 & 26.7 & 38.7 & 17.3 & 340.56 \\
\hline Teacher understands to make reliable and valid assessment & 5.3 & 24.8 & 39.6 & 28.9 & 0.4 & 310.45 \\
\hline $\begin{array}{l}\text { Teacher reports the student's learning achievement to their } \\
\text { parents }\end{array}$ & 20 & 27.6 & 29.8 & 22.7 & 0 & 198.69 \\
\hline $\begin{array}{l}\text { Teacher evaluates student's learning through continuous } \\
\text { internal assessment }\end{array}$ & 6.7 & 35.6 & 40 & 17.3 & 0.4 & 230.78 \\
\hline Teacher helps students to engage in self assessment & 2.7 & 18.7 & 52.4 & 26.2 & 0 & 198.45 \\
\hline
\end{tabular}

Assessment through formal and informal methods is considered to be necessary for teacher as assessment helps to know about the individual differences of learners and assesses students' performance. Empirically it can be said that a very few ESTs were found at desire level of competency in rubric. Teachers assess the students through formal and informal methods. Most of the teachers were under the category of level-3 (Proficient teacher). It is cleared that an unimportant number of ESTs were found at desire level of competency in rubric. Teacher knows various methods of assessment. In this response, most of the teachers were placed under the category of level-3 (proficient teacher). Response 48 showed that most of the ESTs were found at level-2 (developing teacher). No one was found at desire level of competence in rubric.

The growth of learners' based on learning out comes was very much important for teacher as learning outcomes helps to promote students' achievement and to modify instruction in order to foster the continuous development of students. It is concluded that no teachers was found at desired level of competencies. Most of the teachers almost never report the learning achievements of students to their parents. This analysis shows that the calculated value of $\chi 2$ in evaluating student's learning through continuous internal assessment is found to be 230.78 and it is significant and is less than 0.05. Self-assessment was assumed necessary for teacher as it helps to enhance their confidence of their own self-knowledge. Most of the elementary school 
teachers during classroom observation were found at level-2 (Developing teacher). No one was place as accomplished teacher in this rubric.

\section{FINDING AND DISCUSSION}

This research study was based on national professional standards in Pakistan. Government of Pakistan in collaboration of USAID and UNESCO developed ten standards and out of these ten standards, five standards were analyzed in this research study. The analysis enlightens that a large number of elementary school teachers were not competent and efficient as they had no meticulousness regarding the national objectives which ultimately resulted low efficiency [1]. Planning the lesson, organizing the instructions and managing the class room activities are the main characteristics of an efficient and competent teacher, keeping the planning at the top in order to get success and positive results. A competent teacher employs the best method, strategy and techniques to reach this goal [4,5]. But this study revealed that the above mentioned characteristics lack in most of the ESTs.

Islamic values and social life skills are very important for teacher at all levels. Islamic values and social life skills includes Islamic code of conduct, general values, peace in society, Islamic ideology, creation of harmony and moral values. During classroom observation, most of the ESTs were unaware about teaching ethics among students. Only few teachers of Pakistan studies and Islamic studies were found competent who were practicing and inculcating such values among students. A good elementary school needs faculty members who are trained not only in special fields but also in helping to construct the total program of the school [7]. Difference of opinion was observed among the heads of elementary schools, elementary school teachers and students in some areas of competencies such as teachers' command on content which they teach in classrooms. Other weak competencies which were observed during classroom observation were assigning the homework to students, ability of diagnosing the learning difficulties of the students, efficiency in relating the lessons with daily life with the help of suitable examples and finally, assessment of the students during teaching learning process.

Almost all people responded that ESTs did not give importance or value to students on equality basis. They did this, perhaps they had little knowledge and understandings. This insufficiency might be indorsed to the fragile platform of ESTs training where they are not fully trained and equipped with knowledge on all the required prospective such as, how to treat with the students during teaching learning hours. The teachers might want to keep social detachment from the multifaceted, scrambled, and occasionally critical lives of their pupils, but the fact is that they would not be able to teach very well and overlook the several proportions of the lives of their students. The elementary school teachers were also found sluggish and out of the way in constructing test/examination due to the same reason that they had little knowledge and understandings of the criteria of measurement and evaluation; no proper training was conducted to provide them opportunity to overcome their weakness in test construction. A course on measurement and evaluation should be mandatory in all teacher-training programs and teachers should be given tasks of preparing and maintaining records and reports. There is the oral report of individual children, sometimes of the whole class about their progress. There are reports to parents, written and oral.

\section{CONCLUSION}

This research study aimed to evaluate the elementary school teachers through rubrics in district Lodhran. Research questions were developed to determine the personal and professional competencies of the elementary school teachers (ESTs). This is to find out how far these teaching competencies are practiced by the professionally and academically trained EST 
in government middle schools of district Lodhran. The major research question of the study was how existing elementary teachers are practicing different teaching strategies during classroom teaching. Teacher's subject matter knowledge is very important for the effective teaching and learning process. The finding of the study shows that most of the elementary school teachers' almost never know curriculum frame work, basic concepts of acquiring subject knowledge, how to update knowledge and how to explain content in effective way. Most of the teachers sometime demonstrate subject knowledge relating it with practical life of the students.

Results human growth and development showed that most of the elementary teachers did not know how to construct knowledge and diverse learning styles. They almost never committed to increase subject matter competency of students, self-confidence among students and development of critical things among students. Knowledge of Islamic values is very important for every teacher. This study concludes that majority of the elementary school teachers to some extent understand the Islamic code of conduct. Most of elementary school teacher almost never try to promote the general values among students, Islamic teachings to create harmony, resolve conflicts through Islamic teaching, and practicing moral values among students.

This analysis concludes that most of the elementary school teachers to some extent know and understand how to promote students' learning through available resources. The Findings of the study indicate that the pedagogical skills in public schools are not fully utilized. Most of the teachers during observation were found that they almost never used problem explaining approaches during teaching-learning process; they seldom used individual teaching approaches to cope with individual dissimilarities and they also applied teaching situation efficiently. Same was the result found by the researcher in his observation of actual classroom teaching. Use of assessment techniques during classroom is the most important for teachers. According to the results of the study it is quite clear that most of ESTs in district Lodhran did not know the various assessment methods used during classroom. Most of the teachers never engage students in self-assessment, objective based assessment and continuous internal assessment.

\section{References}

Anderson, W. L. (1991). Increasing Teacher Effectiveness. Paris: International Institute for Educational Planning, UNESCO.

Cheema, S., \& Mehmood, K. (1997). Appraisal report of training of teacher educators of GCEs under ICF Programmer of training project. Lahore: Provincial Institute of Teacher Education Punjab.

Connolly, P. (2007). Quantitative data analysis in education: A critical introduction using SPSS. New York: Routledge Taylor \& Francis Group.

Dhand, H. (1990). Techniques of teaching. New Delhi: Shish Publishing House.

Dilworth, E. M. (1991). Diversity in teacher education: New expectations. San Francisco: Jossey-Bass Publishers. Dunkin, M. J. (1997). Assessing teacher's effectiveness. Issues in Educational Research, 7(1), 37-51.

Gilchrist, S. R., Dutton, W. H., \& Wrinkle, W. L. (1985). Secondary education for American democracy. New York: Rinehart and Company Inc.

Government of Pakistan. (1959). National Commission on Education. Karachi: Pakistan Press.

Government of Pakistan. (1998). National Education Policy (1998-2010). Islamabad: Ministry of Education.

Government of Pakistan. (2009). National professional standards for teachers in Pakistan, Policy and Planning wining. Islamabad: Ministry of Education.

Howie, S., \& Plomp, T. (Eds). (2005). Evaluating students' achievements within different contexts. In Prospects. XXXV (1). Paris: International Bureau of Education. UNESCO. 
Haider, S.Z., Qasim. M., \& Ameen. S. (2015). Applying Standardized Rubrics for Assessing the Instructional Competence of Elementary School Teachers (EST) in Pakistan. Advances in Social Sciences Research Journal, 2(3) 38-50.

Feldmann, I., List, T., John, M. T., \& Bondemark, L. (2007). Reliability of a questionnaire assessing experiences of adolescents in orthodontic treatment. The Angle Orthodontist, 77(2), 311-317.

Kalra, A. (1997). Efficient School Management and Role of Principals. New Delhi: A. P. H. Publishing Corporation.

Kurt, S. (1973). The problems of teacher training and the personality of the teacher in education (Vol. 8). Landhausstre: Institute of Scientific Corporation.

Medley, D. M., \& Shannon, D. M. (1994). Teacher evaluation. In T. Husen \& T. N. Postlethwaite (Eds.). The International encyclopedia of education (Vol. 10, 2nd ed.). Oxford: Pergamon.

Panda, B. N., \& Tewari, A. D. (1997). Teacher Education. New Delhi: A. P. H. Publishing Corporation.

Popham, W. J. (1997). What's wrong - what's right - with rubrics? Educational Leadership, 55(2), 72-75.

Schultz, F. (1999). Multicultural Education. Akron: McGraw-Hill.

Shah, R. A. (1997). Education and Teacher Education in Pakistan. Jamshoro: Pakistan studies center, University of Sindh.

Siddiqui, T. K. (2004). A Study of teacher competencies and teaching practices for school effectiveness in Worker Welfare Model School. Unpublished doctoral dissertation, Foundation University, Islamabad.

Sinha, S. (2007). Teaching Competencies in Emerging Indian Society. New Delhi: Adhyayan Publisher \& Distributors.

Stuffle (2003). The Development of Teaching Learning Process. Jaipur: ABD Publishers.

UNESCO (2008). Good Practices and International Trends of Teacher Accreditation and Certification with Analysis and Recommendations for Pakistan under the Strengthening Teacher Education in Pakistan (STEP) Programme. 